Journal of Economics and Behavioral Studies

Vol. 6, No. 7, pp. 569-580, July 2014 (ISSN: 2220-6140)

\title{
Determinants of Working Capital Investment in South Africa: Evidence from Selected JSE- Listed Firms
}

\author{
Farai Kwenda*, Merle Holden \\ University of KwaZulu Natal, South Africa \\ *kwendaf@ukzn.ac.za
}

\begin{abstract}
This paper analyses the determinants of working capital investments of 92 companies listed on the Johannesburg Stock Exchange (JSE) over the period 2001-2010. Working capital management has grown in significance from being a survival issue to a strategic and competitive tool. Using the Generalized Method of Moments estimation, the study found that firms pursue target levels of current assets. However, the adjustment process is relatively slow. The study found that leverage, short-term finance and fixed investment significantly influence the level of working capital investment, while operating cash flows, state of the economy, firm size and sales growth rate were found to be statistically insignificantly related to working capital investment. The study recommends that managers understand the driving factors of working capital investment since working capital investment influences the value of the firm.
\end{abstract}

Keywords: Dynamic, Financing; Investment, Working capital management, Target

\section{Introduction}

Working capital management plays an important role in the realization of the shareholder wealth maximization goal, yet it has largely been ignored in both theoretical and empirical literature at the expense of capital budgeting and capital structure decisions. Working capital was traditionally viewed as a balance sheet item that does not contribute to the realization of the shareholder value maximization goal (Sagner, 2007). However, there has been a paradigm shift in the management of working capital as many executives now regard working capital management as a source of competitive advantage, part of corporate strategy and the overall liquidity and risk management framework of the company (Parkinson, 2011; Yucel \& Kurt, 2002).Working capital management software and programs aimed at generating cash flows through working capital optimization such as the Six Sigma ${ }^{\circledR}$ methodology have been and are being developed. Interestingly, there is growing evidence that firms are overinvesting in working capital. For example, Ernst. and Young (2010) estimated that the largest 1000 American firms and 1000 European firms (by sales) held over US\$450 billion and $€ 475$ billion respectively in working capital unnecessarily. In its 2009 Working Capital Survey of the top 1000 United States (US) companies, REL found that firms were unnecessarily holding approximately US 778 billion in working capital(REL, 2009). Over-investments in working capital compromise shareholder value and can lead to cash flow problems and bankruptcy.

The evidence of working capital over investments raises questions such as do firms have target levels of working capital or do they pursue working capital targets that enable them to maximize shareholder value and minimize costs associated with holding working capital investments as suggested in the literature (Deloof, 2003; Firer, Ross, Westerfield, \& Jordan, 2012). Although there is growing evidence that firms are overinvesting in working capital, the pursuit of target levels of working capital has not attracted the attention of many researchers. The main objective of this study is to determine factors influencing working capital investment and in so doing establish whether South African firms pursue target working investment levels. This study is based on JSE-listed firms drawn from eight sectors of the economy. The rest of the paper is organized as follows: in Section 2, we briefly review literature on working capital investment policies. Data sources and sample are described in Section 3. Section 4 presents and analyses the principal findings of the study. Finally, Section 5 presents the conclusion of the study. 


\section{Literature Review}

Working capital management involves two fundamental decisions: the investment policy and the financing policy of current assets. The investment policy deals with how much to invest in current assets and having an optimal mix of current and fixed assets. The financing policy deals with finding an appropriate mix of shortterm and long-term financing options to support the investments in current assets(Firer et al., 2012). Both working capital financing and investment decisions on current assets involve a trade-off between profitability and risk(Gitman et al., 2010). In common parlance, working capital management is a straightforward subject; making sure that the firm has sufficient liquid resources to meet obligations as they mature. However, in practice finance managers devote much of their time (over 60\%) on working capital management, trying to bring working capital to optimal levels(Van Horne \& Wachowicz, 2004; Weston, Besley, \& Brigham, 1996). There are three working capital investment policies: aggressive (restrictive), conservative (flexible) and the compromise (moderate) approach. Under the aggressive approach, a firm maintains a low current assets-tosales ratio and yields a higher profitability. However, this approach also results in higher risk. A firm holding too few current assets may incur shortages and may face difficulties in maintaining smooth operations (Van Horne \& Wachowicz, 2004).

Under the conservative policy, a firm maintains a relatively large ratio of current assets-to-sales (especially cash), which strengthens a firm's liquidity (and reduces risk). The conservative investment policy has the opportunity cost of lesser profitability and can easily result in a firm realizing a substandard return on investment because it places a greater proportion of capital in liquid assets, which earn either low returns or no returns(Brealey, Myers \& Allen, 2008). The compromise (moderate) approach falls in between conservative and aggressive policies. The implication of this approach is that if a firm takes moderate risk in managing its working capital and yields moderate profitability, the working capital position of the firm will be in optimum balance(Firer et al., 2012).

The cost of holding current assets: Holding working capital investment involves a trade-off between costs that rise and costs that fall with the level of investment in working capital (Firer et al., 2012). Carrying costs are those costs which rise with an increasing level of working capital investment and examples of such costs include storage costs, insurance, obsolescence and the general opportunity costs associated with current assets. Shortage costs decline with an increasing level of working capital investment and examples of such costs include the costs of placing an order for more inventory, lost sales, loss of customer goodwill and disruption of production schedules. The conservative approach results in high carrying costs and low shortage costs. On the other hand, the aggressive approach results in low carrying costs and high shortage costs. Irrespective of which working capital investment policy a firm pursues, an optimal level of current assets holdings exists. The optimal point is where a firm minimizes the total costs, that is, shortage costs plus carrying costs. Firms must pursue a level of working capital investment that enables them to minimize total costs and maximize firm value.

Hill, Kelly, and Highfield (2010) used an unbalanced panel of 3,343 companies from 1996 to 2006 all nonfinancial, nonutility, non-ADR, and SIC-classifiable firms covered by the Compustat database to study net operating working capital. They found that Sales growth, uncertainty of sales, costly external financing, and financial distress encourage firms to pursue more aggressive working capital strategies. Firms with greater internal financing capacity and superior capital market access employ more conservative working capital policies. Baños-Caballero, García-Teruel, and Martínez-Solano (2010) used panel date collected from nonfinancial Spanish SMEs. This study found these SMEs pursue target cash conversion cycle and they quickly adjust towards their target CCC. In addition, they study also found that older firms and companies with greater cash flows maintain a longer CCC, whereas firms with larger leverage, growth opportunities, investment in fixed assets and return on assets maintain a more aggressive working capital policy. A study of the determinants of working capital requirements of 66 firms in Nigeria using panel data for the period 1997-2007 by Akinlo (2012) found that sales growth, firms' operating cycle, economic activity, size, and permanent working capital are firm specific characteristics that positively drive working capital policy. Leverage, however, is inversely related to working capital requirements.

Palombini and Nakamura (2012) used data from 2,976 Brazilian public companies from 2001 to 2008, and 
found that debt level, size and growth rate can affect the working capital management of companies. Using net liquid balance (NLB) and working capital requirements (WCR) as measures of a company's working capital management, Chiou, Cheng, and Wu (2006) found that the debt ratio and operating cash flow affect the company's working capital management. However, the study did not find consistent evidence for the influence of the business cycle, industry effect, growth of the company, performance of the company and firm size on the working capital management. Abuzayed (2012) analyzed relationship between firms' working capital management measured by the cash conversion cycle and market evaluation of managerial skills in managing firms' working capital using data collected from 52 firms listed on the Amman Stock Market. The study found that more profitable firms are less motivated to manage their working capital and financial markets failed to penalize managers for inefficient working capital management in emerging markets. The literature reviewed suggests that there are several firm-specific and non-firm specific factors affecting firms' working capital requirements. It also suggests that firms must have target levels of working capital investment. However, the pursuit of target working capital investment which balances the benefits and costs of working capital investments has not been largely explored empirically. The next section looks at factors affecting working capital investment and the development of the study hypothesis.

\section{Determinants of working capital investment: hypotheses development}

Short-term financing: In imperfect capital markets the investment decisions a firm makes would be influenced by the availability of financial resources among other factors. Following the maturity hedging principle, working capital investment would be financed by short-term funds. It is therefore hypothesized that there is a positive relationship between working capital investment and short-term financing. A firm with more access to short-term funds is expected to hold more current assets.

Sales growth: Sales which represent the accelerator were included as an explanatory variable because the level of investment in working depends on the sales volume. An increase in sales causes an increase in working capital investment, particularly inventory and accounts receivable. Hill et al. (2010)noted that the relationship between sales and working capital investment can suffer from endogeneity problems given that working capital investment can actually influence sales growth. Liberal credit and inventory policies, for example, can stimulate sales growth. Sales growth may induce the firm to invest in more working capital. A positive relationship between sales growth and working capital investment is hypothesized. Sales growth was calculated as:

$$
\text { sgr }=\frac{\text { Sales }_{t}-\text { Sales }_{t-1}}{\text { Sales }_{t-1}}
$$

Operating cash flow (OCF): OCF represents internally-generated financial resources. Internal funds are an important source of working capital finance. Firms with more operating cash flows are able to finance their current assets. Baños-Caballero, Garcia-Teruel, and Martinez-Solano (2009)and Hill et al. (2010)used operating cash flow to represent internal financing. Operating cash flow was calculated as follows: Operating Income minus taxes plus depreciation. It is hypothesized that internal financing and working capital investment are positively related.

Fixed Investment: Fixed investment was used as an explanatory variable in order to determine whether fixed and working capital compete for investment funds or complement each other. If fixed investment competes for funds with working capital investment, a negative coefficient is hypothesized. A positive coefficient means that fixed investment and working capital complement each other; that is, firms increase their working capital investment when they increase their fixed investment.

Market Power: A firm with greater negotiating power can invest less in working capital by holding fewer inventories and imposing short credit terms with their customers. Therefore, an inverse relationship between market power and working capital investment is hypothesized. Market power was calculated as given below:

$$
\text { market power }=\frac{\text { Firm's annual sales }}{\text { Total Industry Annual Sales }}
$$

Firm size: As the size of a firm increases, the level of working capital investment required also increases in 
order to sustain operations at a higher level. These current assets have to be financed partly by current liabilities. Size has also been used as a proxy for access to external funds. Creditworthy and large firms have superior access to external capital and, therefore, are better positioned to finance their investment in working capital. Therefore, it is difficult to predict the direction of influence of firm size. FollowingHill et al. (2010), the study uses the natural logarithm of market value of equity as a proxy for firm size.

Business cycle: A country's level of economic activity influences a firm's level of working capital investment. However, its direction of influence is difficult to hypothesize. A slowdown in the economy reduces the ability to turn over current assets to generate sales, resulting in huge current asset holdings. For example, a contraction in the economy affects the ability to collect its receivables and the ability to turn over inventory into sales; resulting in high inventory investment. In an expansion phase, firms increase their working capital investment in order to match the increase in business activity. Receivables increase as a result of more sales and could also increase as a result of liberal credit policies. In a good economic phase, firms can afford to extend liberal credit terms to their customers, resulting in high receivables levels. In order to control the influence of business cycles, Real Growth Domestic Product (RGDP) growth rate, which measures the growth of the South African economy, was included in the regression.

\section{Methodology}

The empirical study is based on a sample of 92 firms listed on the JSE in the following sectors: chemical and oil sector, consumer goods, retail, industrials, mining, leisure and recreation, and technology, as classified by the McGregor BFA Library. Sample firms' data were collected from the financial statements for the accounting period 2001 to 2010. Firms with missing financial statements were excluded in order to produce a balanced panel. Consistent with some previous studies,(Deloof, 2003; Mathuva, 2009), firms in the banking, financial services and real estate sectors were excluded from the sample.

Model Specification: To understand the factors influencing the investment in gross working capital, the study adopts a dynamic approach instead of a static approach as in some previous studies. Holding current assets involves a trade-off between carrying costs and shortage costs and there exists an optimal point where a firm minimizes the total costs regardless of the working capital approach a firm chooses to pursue. The existence of an optimal working capital investment level means firms try to move towards the target should the level of current assets not be at the optimal level. Secondly, the actual levels of current assets may not always equal the desired levels and firms take time to adjust from real to desired levels. Such variances between the real and desired levels exist because of the difficulties in estimating with certainty the level of sales and purchases.

The Empirical Model: The study uses a dynamic approach following the footsteps of García-Teruel and Martínez-Solano (2010) analyzing the determinants of accounts payable. The empirical working capital investment model (see Appendix A for model development) is given below.

$$
\begin{aligned}
& \text { CATA }_{i t}=\beta_{0}+\beta_{1} \text { CATA }_{i t-1}+\beta_{2} \text { CLTA }_{i t}+\beta_{3} P_{\text {GROWTH }_{i t}}+\beta_{4} N_{G_{\text {GOWTH }}}+\beta_{5} \text { SIZE }_{i t} \\
& +\beta_{6} \text { FIXTA }_{i t}+\beta_{7} \text { OCFTA }_{i t}+\beta_{8} L E V E R A G E_{i t}+\beta_{9} R G D P_{i t}+\beta_{10} \text { MKTPOWER }_{i t}+\eta_{i}+n_{t} \\
& +\varepsilon_{i t} \ldots \ldots \ldots \ldots \ldots \ldots \ldots 1
\end{aligned}
$$

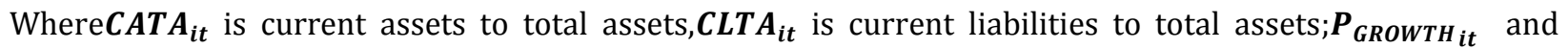

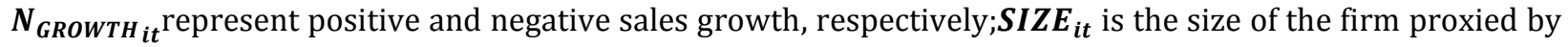

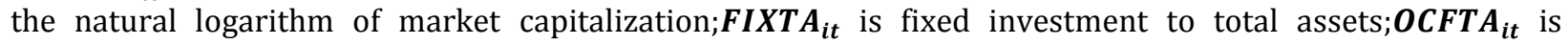
operating cashflows to total assets; $\boldsymbol{M K T P O W E R _ { i t }}$ is the market power of the firm;RGDP $\boldsymbol{P}_{\boldsymbol{i t}}$ is Real Growth

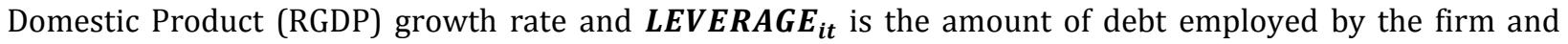
deflated by total assets; $\boldsymbol{\eta}_{\boldsymbol{i}}$ represents unobservable heterogeneity; $\boldsymbol{n}_{\boldsymbol{t}}$ are the time dummy variables and $\boldsymbol{\varepsilon}_{\boldsymbol{i}}$ is the error term.

Descriptive Statistics: Table 1 presents the descriptive statistics of the variables used in the study. Current assets to total assets investments are $64 \%$ (median values is $66 \%$ ) with a volatility of $22 \%$. The 10 per centile and the 90 per centile have $33 \%$ and $91 \%$, respectively, of their total assets as current assets. The respective 
averages of $\mathrm{P}_{\text {GROWтH }}$ and $\mathrm{N}_{\text {GRоWтн }}$ are $26 \%$ and $-3.5 \%$. The average operating cash flows to total assets are $20 \%$ (median value of $17 \%$ ) with a volatility of $17 \%$. The average fixed investment to total assets is $6 \%$ with a median value of $5 \%$. The 10 per centile has an almost negligible amount of fixed investment while the 90 per centile fixed investment to total assets was $15 \%$. The mean market power obtained is $9 \%$ and the median value is $3 \%$, which shows that many firms in this study do not have significant market power. The average market capitalization of firms in the sample was R16 billion, which shows that the sample comprises large firms. On average the South African economy grew by 3.5\% between 2001 and 2010. Approximately 60\% of the assets held by the sample were financed by debt as shown by the mean debt ratio. The 10 and 90 per centile use debt to finance $30 \%$ and $84 \%$ of their total assets, respectively. On average current liabilities to total assets are $47 \%$ (median value was $43 \%$ ). Trade creditors to total assets (TCTA) are $32 \%$ (median value is $29 \%$ ), which means that trade credit finances almost a third of the total assets of firms used in this study. The mean STDTA is $9 \%$ (median value is $6 \%$ ).

Table 1: Descriptive Statistics

\begin{tabular}{|c|c|c|c|c|c|c|}
\hline Variable & Definition & Mean & Std. Dev. & Median & Perc10 & Perc 90 \\
\hline CATA & Current Assets / Total assets & 0.6431 & 0.2230 & 0.6570 & 0.3312 & 0.9127 \\
\hline OCFTA & $\begin{array}{l}\text { Operating cash flows /Total } \\
\text { assets }\end{array}$ & 0.1983 & 0.1658 & 0.1697 & 0.0792 & 0.3535 \\
\hline LEVERAGE & Total debt / total assets & 0.5937 & 0.2861 & 0.57 & 0.31 & 0.84 \\
\hline GROWTH & Sales growth & 0.2221 & 0.6387 & 0.13 & -0.11 & 0.5 \\
\hline $\mathrm{P}_{\text {GROWTH }}$ & Positive sales growth & 0.2576 & 0.6071 & 0.13 & 0 & 0.5 \\
\hline $\mathrm{N}_{\text {GROWTH }}$ & Negative sales growth & -0.0354 & 0.1454 & 0 & -0.11 & 0 \\
\hline SIZE & Market capitalization (000 000s) & 16000 & 49600 & 2150 & 113 & 28800 \\
\hline CLTA & Current liabilities / total assets & 0.4658 & 0.2199 & 0.4309 & 0.2090 & 0.7385 \\
\hline STDTA & Short-term debt /total assets & 0.0904 & 0.1104 & 0.0596 & 0.0003 & 0.219 \\
\hline TCTA & Trade creditors / total assets & 0.3212 & 0.1823 & 0.2862 & 0.1264 & 0.6074 \\
\hline ACCTA & Accruals / total assets & 0.0542 & 0.0712 & 0.0348 & 0.046 & 0.1112 \\
\hline FIXTA & Fixed investment / total assets & 0.064 & 0.0859 & 0.0485 & 0.0027 & 0.1546 \\
\hline MKTPOWER & Firm sales / sector sales & 0.0934 & 0.1434 & 0.027 & 0.002 & 0.29 \\
\hline RGDP & RGDP growth rate & 0.035 & 0.0066 & - & - & - \\
\hline
\end{tabular}

Source: Own calculations using a balanced panel over the period 2001 to 2010. Data obtained from the McGregor BFA library.

The Correlation Matrix: Table 2 presents the results of the correlation analysis between variables used in this study. The correlation between CATA and independent variables in the correlation matrix follow the expected signs (with the exception of leverage), though some are statistically insignificant. In addition, the study does not find high correlation between independent variables, which could lead to the problem multicollinearity and inconsistent estimations. A positive correlation was found between current assets and shortterm financing, demonstrating the importance of short-term finance in financing short-term assets. This can also be seen as proof that these firms follow the matching principle where firms match short-term assets maturities with short-term liabilities.

The proxy for firm size used in this study (natural logarithm of market capitalization) shows a statistically significant negative correlation with current assets, suggesting that large firms invest less in working capital. The negative correlation supports the notion that bigger firms are better positioned to manage the supply chain (Palombini \& Nakamura, 2012) and can employ experts in managing their working capital, hence the low working capital holdings. The correlation between CATA, RGDP and the performance of the economy is positive as anticipated but not statistically significant. Similarly, the correlation between CATA and market power is negative as expected, however, it is not statistically proved. Fixed investment and working capital investment have a statistically significant negative relationship, which supports the view that competition for funds exists between fixed investments and working capital investments. The study did not find any statistically significant relationship between CATA and both positive sales growth (PGROWTH) and negative 
sales growth (NGROWTH).

Table 2: Correlation matrix

\begin{tabular}{|c|c|c|c|c|c|c|c|c|c|c|c|c|}
\hline & $\begin{array}{l}\text { CAT } \\
\text { A }\end{array}$ & CLTA & TCTA & $\begin{array}{l}\text { STD } \\
\text { TA } \\
\end{array}$ & $\begin{array}{l}\text { ACC } \\
\text { TA } \\
\end{array}$ & $\begin{array}{l}\text { FIXT } \\
\text { A }\end{array}$ & $\begin{array}{l}\text { LNMC } \\
\text { AP }\end{array}$ & $\begin{array}{l}\text { OCF } \\
\text { TA }\end{array}$ & $\begin{array}{l}\text { RGD } \\
\mathbf{P} \\
\end{array}$ & $\begin{array}{l}\text { LEVER } \\
\text { AGE }\end{array}$ & $\begin{array}{l}P_{\text {GRO }} \\
\text { WTH }\end{array}$ & $\begin{array}{l}\mathbf{N}_{\text {GRO }} \\
\text { WTH }\end{array}$ \\
\hline CATA & $\begin{array}{l}1.00 \\
0.58^{*}\end{array}$ & & & & & & & & & & & \\
\hline CLTA & $\begin{array}{l}* * \\
0.55^{*}\end{array}$ & $\begin{array}{l}1.00 \\
0.81^{*}\end{array}$ & & & & & & & & & & \\
\hline TCTA & $\begin{array}{l}* * \\
0.10^{*}\end{array}$ & $\begin{array}{l}* * \\
0.50 *\end{array}$ & 1.00 & & & & & & & & & \\
\hline STDTA & $* *$ & $*$ & $\begin{array}{l}0.01 \\
-\end{array}$ & 1.00 & & & & & & & & \\
\hline & $0.20^{*}$ & $0.24^{*}$ & $0.08^{*}$ & & & & & & & & & \\
\hline ACCTA & $\begin{array}{l}* * \\
-\end{array}$ & $\begin{array}{l}* * \\
-\end{array}$ & * & -0.04 & $\begin{array}{l}1.00 \\
-\end{array}$ & & & & & & & \\
\hline FIXTA & $\begin{array}{l}0.34^{*} \\
* * \\
-\end{array}$ & $\begin{array}{l}0.10^{*} \\
* *\end{array}$ & $\begin{array}{l}0.13^{*} \\
* \\
-\end{array}$ & $\begin{array}{l}0.07 \\
* *\end{array}$ & $\begin{array}{l}0.08 \\
* *\end{array}$ & 1.00 & & & & & & \\
\hline LNMCA & $0.20^{*}$ & & $0.16^{*}$ & & 0.30 & & & & & & & \\
\hline $\mathrm{P}$ & $* *$ & -0.02 & * & 0.04 & $* * *$ & 0.04 & 1.00 & & & & & \\
\hline & 0.060 & $0.09 *$ & $0.19 *$ & 0.10 & 0.60 & & $0.27^{* *}$ & & & & & \\
\hline OCFTA & $\begin{array}{l}0^{*} \\
0.020\end{array}$ & $\begin{array}{l}* * \\
0.07 *\end{array}$ & $* *$ & *** & $\begin{array}{l}* * * \\
0.13\end{array}$ & -0.03 & * & $\begin{array}{l}1.00 \\
0.12\end{array}$ & & & & \\
\hline RGDP & 0 & $*$ & 0.04 & -0.01 & $* * *$ & $0.06^{*}$ & 0.02 & $* * *$ & 1.00 & & & \\
\hline LEVER & $0.18^{*}$ & $0.62^{*}$ & $0.54^{*}$ & 0.34 & & $0.08^{*}$ & & & & & & \\
\hline AGE & $\begin{array}{l}* * \\
0.020\end{array}$ & $\begin{array}{l}* * \\
0.10^{*}\end{array}$ & $\begin{array}{l}* * \\
0.07 *\end{array}$ & $\begin{array}{l}* * * \\
0.07\end{array}$ & 0.01 & $\begin{array}{l}* * \\
0.10^{*}\end{array}$ & 0.01 & -0.03 & 0.04 & 1.00 & & \\
\hline $\mathrm{P}_{\text {GROWTH }}$ & $\begin{array}{l}0 \\
- \\
0.010\end{array}$ & $* *$ & * & $* *$ & $\begin{array}{l}0.02 \\
0.06\end{array}$ & $\begin{array}{l}* * \\
0.16^{*}\end{array}$ & 0.02 & 0.00 & $\begin{array}{l}0.01 \\
0.11\end{array}$ & $0.13^{* * *}$ & $\begin{array}{l}1.00 \\
0.10^{*}\end{array}$ & \\
\hline $\mathrm{N}_{\text {GROWTH }}$ & 0 & 0.05 & 0.04 & -0.01 & $* * *$ & $* *$ & 0.05 & 0.05 & $* * *$ & -0.03 & $* *$ & 1.00 \\
\hline
\end{tabular}

${ }^{*}, * *$ and ${ }^{* * *}$ significant at $10 \%, 5 \%$ and $1 \%$ respectively

Source: Own calculations using a balanced panel over the period 2001 to 2010. Data obtained from the McGregor BFA library.

\section{Results}

All equations were estimated using the two-step first-difference Generalized Method of Moments (GMM) approach suggested by Arellano and Bond (1991)using the same dependent variable, CATA. The coefficient estimates of the equation are presented in Table 3. The consistency of the estimations was confirmed because no second-order serial correlation in the first difference residuals is detected using the $\mathrm{m}_{2}$ statistic. The Sargan test was used to test for overidentifying restrictions that also indicate the absence of correlation between instruments and error term. Column I present the results when the Equation 1was estimated excluding time dummies. In models 2 and 4, time dummies are included and the explanatory variable RGDP is dropped because it is correlated with the time dummies. Column 3 repeats the estimation disaggregating short-term finance; CLTA, into different components: trade credit, short term debt and accruals but without time dummies.

The lagged dependent variable, $C A T A_{i t-1}$ : The coefficient of the lagged dependent variable, $\mathrm{CATA}_{i t-1}$, is positive and statistically significant at $1 \%$ in all models in Table 3, which confirms the principal argument of this study. CATA ${ }_{i t-1}$ is precisely defined in all models; therefore, the dynamic approach used in this study is not 
rejected. The results also show that working capital investment levels are persistent over time. South African listed firms have target working capital investment levels and they partially adjust their working capital investment level in an attempt to reach this target. The adjustment coefficient, which is given by 1 minus the coefficient of the lagged dependent variable $\mathrm{CATA}_{i t-1}$, is 0.41 in model 1 , providing some evidence that the speed of adjustment by these firms towards their target working capital investment level is relatively slow. In model 3, current liabilities were disaggregated into trade credit, short-term debt and accruals. The coefficient of the lagged dependent $\mathrm{CATA}_{i t-1}$ was also statistically significant at $1 \%$, further supporting the principal argument of this study. The adjustment coefficient is 0.53 , which is slightly higher (8 percentage points) than those reported in model 1, and could be an indication that the speed of adjustment is affected by the nature of the short-term financing mix used by these firms. In models 2 and model 4, time dummies were included and the respective speeds of adjustment towards the target working capital investment level reported were 0.48 and 0.42, respectively. These findings suggest that South African listed firms pursue a target level of working capital investment that enables them to minimize carrying and shortage costs (Firer et al., 2012). These findings also suggest that these firms pursue a level of working capital investment that enables them to maximize shareholder value and profitability as suggested by Deloof (2003)andDamodaran (2001).

The adjustment costs are inversely related to the speed of adjustment. Firms that quickly adjust towards their target face low adjustment costs and vice versa. The average speed of adjustment is about 0.5 , therefore it can be said that firms in the sample face moderate costs of adjusting towards their target working capital investment level. Baños-Caballero et al. (2009)state that the adjustment process is a trade-off between the cost of adjusting towards the target and the cost of being off-target. If the costs of being in disequilibrium are higher than the adjustment costs, then firms adjust very quickly and vice versa. The findings of the study seem to suggest that these firms adjust slowly, which implies the low costs of being in disequilibrium. The average speed of adjustment of the study is 0.5 , which means that firms do not instantaneously adjust towards their target. Firms take time to adjust towards their target.

Leverage: The hypotheses that, with increasing debt levels, firms reduce their levels of working capital investment are confirmed as the coefficient of leverage is negative and statistically significant in all the four models. Its coefficient is, significant at $10 \%$ in models 1 and 2 and in model 3 and 4 it is significant at $5 \%$. These results are consistent with previous studies that used working capital requirements to total assets (WCR_TA) as the dependent variable(Akinlo, 2012; Baños-Caballero et al., 2010; Chiou et al., 2006; Nazir \& Afza, 2009; Palombini \& Nakamura, 2012). As leverage increases, firms pay attention to their working capital investment to avoid overinvestment and minimize funds being tied up in working capital.

Table 3: Determinants of working capital investment CATA

\begin{tabular}{llllll}
\hline & $(\mathbf{1})$ & $\mathbf{( 2 )}$ & $\mathbf{( 3 )}$ & $\mathbf{( 4 )}$ & $\mathbf{( 5 )}$ \\
\hline CATA $_{\text {it-1 }}$ & $0.588^{* * *}$ & $0.518^{* * *}$ & $0.473^{* * *}$ & $0.477^{* * *}$ & $0.585^{* * *}$ \\
CLTA & $(3.26)$ & $(3.67)$ & $(2.95)$ & $(3.47)$ & $(3.20)$ \\
& $0.311^{* * *}$ & $0.258^{* * *}$ & - & - & $0.285^{* *}$ \\
TCTA & $(2.67)$ & $(2.79)$ & - & - & $(2.42)$ \\
& - & - & $0.402^{* * *}$ & $0.401^{* * *}$ & - \\
STDTA & - & - & $(2.84)$ & $(2.73)$ & - \\
& - & - & $0.229^{* *}$ & $0.176^{* *}$ & - \\
ACCTA & - & - & $(2.30)$ & $(2.31)$ & - \\
& - & - & $0.445^{* * *}$ & $0.334^{* * *}$ & - \\
PGROWTH & - & $-3.01)$ & $(2.97)$ & - \\
$\mathrm{N}_{\text {GROWTH }}$ & 0.00245 & 0.00143 & 0.00250 & 0.00249 & 0.0037 \\
SIZE & $(0.43)$ & $(0.22)$ & $(0.58)$ & $(0.47)$ & $(0.59)$ \\
& 0.0210 & 0.0132 & 0.0179 & 0.00682 & 0.16 \\
FIXTA & $(1.12)$ & $(0.75)$ & $(1.01)$ & $(0.41)$ & $(094)$ \\
& -0.00296 & $0.0187^{* *}$ & -0.00387 & 0.0134 & -0.004 \\
OCFTA & $(-0.39)$ & $(2.29)$ & $(-0.55)$ & $(1.81)$ & $(-0.49)$ \\
& $-0.266^{* * *}$ & $-0.270^{* * *}$ & $-0.237^{* * *}$ & $-0.247^{* * *}$ & $-0.279^{* * *}$ \\
& $(-3.26)$ & $(-3.77)$ & $(-3.03)$ & $(-3.45)$ & -3.32 \\
& 0.00322 & -0.00442 & -0.00717 & -0.0127 & 0.0067
\end{tabular}




$\begin{array}{llllll} & (0.06) & (-0.10) & (-0.15) & (-0.29) & 0.14 \\ \text { RGDP } & 0.104 & - & 0.0233 & - & 0.150 \\ \text { LEVERAGE } & (0.80) & - & (0.17) & - & (0.73) \\ & -0.134^{*} & -0.0872^{*} & -0.152^{* *} & -0.110^{* *} & -0.1417^{* *} \\ \text { MKTPOWER } & (-1.86) & (-1.66) & (-2.38) & (-2.35) & (-2.06) \\ & -0.0408 & -0.0696 & -0.0284 & -0.0388 & -0.536 \\ \text { CRISIS } & (-0.85) & (-1.17) & (-0.59) & (-0.63) & (-1.06) \\ & - & - & - & - & 0.0037 \\ \text { CONS } & - & - & - & - & (0.54) \\ & 0.285 & -0.113 & 0.361 & -0.0137 & 0.329 \\ \text { Time dummies } & (1.28) & (-0.61) & (1.74) & (-0.08) & (1.47) \\ \text { m } 2 & - & \text { Yes } & - & \text { Yes } & - \\ \text { Sargan test } & 0.2638 & 0.1818 & 0.3016 & 0.1775 & 0.2360 \\ \text { Df } & 26.21 & 32.42 & 26.69 & 31.56 & 30.37 \\ \text { p-values } & 20 & 20 & 20 & 20 & 20 \\ & 0.1465 & 0.039 & 0.144 & 0.05 & 0.064\end{array}$

t statistics in parenthesis. * ** and ${ }^{* * *}$ denote significance at $10 \%, 5 \%$ and $1 \%$, respectively.

Time dummies' coefficients not reported for brevity.

Source: Own calculations using a balanced panel over the period 2001 to 2010. Data obtained from the McGregor BFA library

Palombini and Nakamura (2012)argue that firms with high leverage pursue a more efficient working capital management approach in order to avoid issuing new debt and equity. Leverage has a very significant economic impact ${ }^{1}$. A one increase standard deviation in LEVERAGE results in a working capital investment decrease by $17 \%$ and 19\% in models 1 and 2, respectively. In models 3 and 4, the same increase in leverage produces a decrease in working capital investment by $11 \%$ and $14 \%$, respectively. The high economic impact of the variable is consistent with the views and findings of studies on the capital structure of South African listed firms. Capital structure studies on South African listed firms such as Fosu (2013) support the view of van Zyl (2012) that South African firms are generally underleveraged. A study by Erasmus (2009) on pre1994 and post-1994 capital structures of listed industrial firms, found that in most years of the study period long-term debt averaged $10 \%$ or less to the overall capital requirement. Erasmus attributes this debt aversion to the volatility of market interest rates and the unstable South African Rand / US\$ dollar exchange rate.

Fixed investment: The negative correlation between fixed investment and working capital investment is confirmed by the regression analysis. In all the four models the relationship between working capital investment and fixed assets investment, FIXTA, is negative and statistically significant at $1 \%$, which validates the hypothesis that working capital and fixed investment compete for funds. This is consistent with the previous studies of Gupta (2003) on the food processing industry in India, and Appuhami (2008) in a study of firms in Thailand. Working capital and fixed investment compete for a limited pool of funds for a financially constrained firm. When a financially constrained firm increases its fixed investment, its working capital investment will decrease and vice versa, ceteris paribus. Fixed investment has a significant economic impact, since working capital investment declines by $10 \%$ on average when FIXTA increases by one standard deviation.

Short-term financing: The coefficient of CLTA is positive and statistically significant at $1 \%$ in all the models. As firms access more short-term finance, firms hold more or invest more assets in working capital. The positive association between CATA and CLTA brings more evidence that these firms follow the matching principle. The matching principle ensures that cash flows generated by assets are sufficient to pay periodic debt payments. According to Myers (1977) the matching of assets and liabilities helps firms minimize the agency problem between debt holders and shareholders. Short-term finance comprises trade credit, accruals and short-term debt. The study explored which of three sources are mainly used to finance working capital

\footnotetext{
${ }^{1}$ The economic impact was calculated as the coefficient of a statistically significant independent variable multiplied by its standard deviation divided by the standard deviation of the dependent variable.
} 
investment. Spontaneous sources (trade credit and accruals) significantly explain the working capital investment level of these listed firms rather than short-term debt. Trade credit is significant at $1 \%$ in models 3 and 4. The high significance of spontaneous sources is probably one of the reasons why there is very limited participation or lack of appetite for bonds in South Africa by listed firms, in particular the commercial paper market. Both trade credit and accruals are more significant in their economic impact than short-term debt. While a one standard deviation increase in TCTA results in an increase in working capital investment of 33\%, for accruals it produces an increase of $14 \%$ and $11 \%$ for model 3 and model 4 , respectively. These figures are higher than the economic impact of short-term debt, which produces an increase in working capital investment of $11 \%$ and $9 \%$ for model 3 and model 4 , respectively.

Operating cash flows: Contrary to expectation and some previous studies (Chiou et al., 2006; Hill et al., 2010), this study finds a statistically insignificant relationship between working capital investment and operating cash flows. In column 1, the relationship is positive while in the rest of the models, the relationship is negative and statistically insignificant, which is consistent with the findings of Nazir and Afza (2009). These findings might suggest that these firms do not follow the pecking order in financing their working capital investment. Alternatively, these findings are an indication of the wider sources of finance available to these large firms or they suggest that firms do not necessarily accumulate resources to finance their working capital.

Size: The study does not find any evidence in support of the size effect on working capital investment, consistent with Baños-Caballero et al. (2010) and Palombini \& Nakamura (2012). However, this is contrary to the findings of Chiou et al. (2006), Hill et al. (2010) and Jose, Lancaster, and Stevens (1996).Therefore, the hypothesis that bigger firms hold more working capital investment in order to sustain operations at a higher level or can finance their working capital investment more easily because they have better access to financial markets is not confirmed.

Market power: The relationship between market power and working capital investment of sample firms is negative as expected but it is not statistically proved, consistent with Hill et al. (2010) and Kieschnick, LaPlante, and Moussawi (2013). Descriptive statistics show that the average market power of firms in the sample is $9 \%$ and the median value is $3 \%$, which shows that most firms in this sample do not have significant market power. The statistically insignificant negative coefficient of the regression and correlation between market power and working capital investment probably suggest that for these firms their market power might not be large enough to affect their level of working capital investment.

Sales growth: Both negative and positive sales growths had statistically insignificant relationships with working capital investment. Sales growth rate and growth opportunities tend to wane as a firm gets older and more established in business (Chiou et al., 2006). The insignificant relationship between working capital investment and sales growth could be explained by the fact that the sample comprised large well-established firms which have low growth opportunities.

Business cycle: The statistically insignificant correlation between working capital investment and the state of the economy is also confirmed by the positive statistically insignificant relationship in the regression results. This is consistent with some previous studies (Akinlo, 2012; Lamberson, 1995; Nazir \& Afza, 2009) which did not find any evidence that the level of working capital investment depends on the state of the economy. However, this finding is contrary to Abuzayed (2012) who found that working capital management efficiency depends on the state of economy in a study of Jordanian firms. Lamberson (1995)argues that finance managers generally need more time to adjust to economic conditions. Economic conditions tend to change faster than the ability of firms to change their levels of working capital investment. The study used annual financial statements and annual RGDP growth. Probably, a different result could have been obtained if quarterly financial statements were regressed against quarterly RGDP in order to capture the impact of the peaks and troughs that the South African economy experienced between 2001 and 2010. Semi-annual financial statements are the shortest period available from JSE-listed firms as they are required to publish interim and final financial statements. Most interim financial reports do not have some of the variables that were used in this study and therefore they could not be used. In their study, Chiou et al. (2006)used quarterly data and found that working capital management was sensitive to the state of the economy. 
Economic crisis: An attempt was made to assess the 2008-2009 financial crises' impact on working capital investment levels of South African listed firms. In model 5 the dummy variable, CRISIS, which took the form 1 (and 0 otherwise) to represent the period of the financial crisis, the years 2008 and 2009 was introduced. A possible explanation for the non-significance of the dummy variable, CRISIS, could be that reductions in working capital investments were not universal during 2008-2009. Correia, Flynn, Uliana, and Wormald (2011)state that some firms did not reduce their working capital investment and use the example of Cashbuild, which did not change its inventory levels during the 2008-2009 global economic crises. Another possible explanation for these results is the fact that the economic crisis did not last very long. The South African Government declared that the economy had officially entered a recession in May 2008, long after developed economies had done so.

\section{Conclusion}

The purpose of the study was to analyze factors influencing working capital investment using JSE-listed firms drawn from eight economic sectors over the period 2001 to 2010. The study used a dynamic panel data and employed GMM estimation techniques in order to control for endogeneity and unobservable heterogeneity. The study found that South African-listed firms pursue target working capital investment levels and they adjust relatively slowly towards their target levels. For these firms, working capital investment is influenced by leverage, fixed investment and short-term finance. Working capital investment constitutes a significant portion of a firm's assets and impacts on shareholder value; therefore, it is important for managers to understand the key factors that drive the working capital investment level of their firms.

\section{References}

Abuzayed, B. (2012). Working capital mangement and firm's performance in emerging markets: the case for Jordan. International Journal of Managerial Finance, 8(2), 155-179.

Akinlo, O. O. (2012). Determinants of Working Capital Requirements in Selected Quoted Companies in Nigeria. Journal of African Business, 13(1), 40-50.

Appuhami, B. R. (2008). The impact of firms' capital expenditure on working capital management: an empirical study across industries in Thailand. International Management Review, 4(1), 8-21.

Arellano, M. \& Bond, S. R. (1991). Some tests of specification for panel data Monte Carlo evidence and an application to employment equations. Review of Economic Studies, 58, 277-297.

Baños-Caballero, S., Garcia-Teruel, P. J. \& Martinez-Solano, P. (2009). How do market imperfections affect working capital management? Working papers= Documentos de trabajo: Serie EC (Instituto Valenciano de Investigaciones Económicas, (14), 1.

Baños-Caballero, S., García-Teruel, P. J. \& Martínez-Solano, P. (2010). Working capital management in SMEs. Accounting \& Finance, 50(3), 511-527.

Brealey, R. A., Myers, S. C. \& Allen, F. (2008). Principles of Corporate Finance (9th International ed.). New York: McGraw Hill/Irwin.

Chiou, J. R., Cheng, L. \& Wu, H. W. (2006). The determinants of working capital management. Journal of American Academy of Business, 10(1), 149-155.

Correia, C., Flynn, D., Uliana, E. \& Wormald, M. (2011). Financial managment (7th ed.). Cape Town: Juta

Damodaran, A. (2001). Corporate Finance: Theory and Practice (2nd ed.). New York: John Wiley \& Sons

Deloof, M. (2003). Does working capital management affect profitability of Belgian firms? Journal of Business Finance \& Accounting, 30(3-4), 573-588.

Erasmus, P. D. (2009). Capital structure and debt maturity choices for South African firms: Evidence from a highly variable economic environment.

Ernst, L. \& Young, G. (2010). All tied-up Working capital management report -2010. http://www.ey.com/Publication/vwLUAssets/All-tied-up_2010/\$FILE/All-tied-up_2010.pdf

Firer, C., Ross, S. A., Westerfield, R. W. \& Jordan, B. D. (2012). Fundamentals of Corporate Finance (5th Ed ed.). Berkshire McGra-Hill Education

Fosu, S. (2013). Capital structure, product market competition and firm performance: Evidence from South Africa. The Quarterly Review of Economics and Finance.

García-Teruel, P. J. \& Martínez-Solano, P. (2010). A dynamic perspective on the determinants of accounts payable. Rev Quant Finan Acc, 34, 439-457. doi: 1007/s11156-009-0124-0 
Gitman, L. J., Beaumont Smith, M., Hall, J., Lowies, B., Marx, J., Strydom, B. \& van der Merwe, A. (2010). Principles of Managerial Finance: Global and South African Perspectives (1st edition ed.). Cape Town: Pearson Education South Africa

Gupta, S. (2003). Management of Working capital Delhi: New Century Publications

Hill, M. D., Kelly, G. W. \& Highfield, M. J. (2010). Net operating working capital behavior: a first look. Financial management, 39(2), 783-805.

Jose, M. L., Lancaster, C. \& Stevens, J. L. (1996). Corporate returns and cash conversion cycles. Journal of Economics and Finance, 20(1), 33-46.

Kieschnick, R., LaPlante, M. \& Moussawi, R. (2013). Working Capital Management and Shareholders' Wealth. Review of Finance. doi: doi: 10.1093/rof/rfs043

Lamberson, M. (1995). Changes in working capital of small firms in relation to changes in economic activity. American Journal of Business, 10(2), 45-50.

Mathuva, D. (2009). The influence of working capital management components on corporate profitability: a survey on Kenyan listed firms. Research Journal of Business Management, 3(1), 1-11.

Myers, S. C. (1977). Determinants of corporate borrowings. Journal of Financial Economics, 5(147-175).

Nazir, M. S. \& Afza, T. (2009). Impact of aggressive working capital management policy on firms' profitability. The IUP Journal of Applied Finance, 15(8), 19-30.

Palombini, N. V. N. \& Nakamura, W. T. (2012). Key Factors In Working Capital Management In The Brazilian Market. RAE, 52(1), 55-69.

Parkinson, K. (2011). Improving working capital management and cash flow intelligence. http://www.protiviti.com/en-US/Documents/White-Papers/Risk-Solutions/APQC-ProtivitiWorking-Capital-Management-Study.pdf

REL. (2009). The Working Capital Survey REL / CFO Magazine 2009.

Sagner, J. S. (2007). Why working capital drives M \& A today. Journal of Corporate Accounting and Finance, 2, 41-45.

Van Horne, J. C. \& Wachowicz, J. C. (2004). Fundamentals of Financial management (12th ed.). New York: Prentice Hall Publishers.

Van Zyl, C. (2012). The Bond Market. In C. van Zyl, Z. Botha, P. Skerritt \& I. Goodspeed (Eds.), Understanding the South African Financial Markets (4th ed.). Pretoria: Van Schaik Publishers.

Weston, J. F., Besley, S. \& Brigham, E. F. (1996). Essential of Managerial Finance (11th ed.). Forth Worth:: The Dryden Press Harcourt Brace College Publishers.

Yucel, T. \& Kurt, G. (2002). Cash conversion cycle, cash management and profitability: An empirical study on the ISE traded companies. The ISE Review, 6(22), 1-15.

\section{Appendix A - Model development}

The study assumes that firms have a target working capital investment level (current assets $(C A T A)$ ). The target working capital investment level for firm $i$, at time $t$ denoted as $C A T A_{i t}^{*}$ will be specified a vector of firm and time-varying variables and these variables determine the firm's target working capital investment level as well as firm and time-specific effects represented by firm and time dummy variables.

The change in the actual working capital investment level for firm $i$, at time $t-1$ to $t$ will be equal to the change required to attain the target level at time $t$ as shown below.

$$
\text { CATA }_{i, t}-\text { CATA }_{i, t-1}=\left(\text { CATA }_{i, t}^{*}-\text { CATA }_{i, t-1}\right) \ldots
$$

We then assume that firms adjust their working capital investment level according to the degree of adjustment coefficient $\lambda$ in order to approach their target level:

$$
C A T A_{i, t}-\text { CATA }_{i, t-1}=\lambda\left(\text { CATA }_{i, t}^{*}-\text { CATA }_{i, t-1}\right)
$$

The expression $C A T A_{i t}^{*}-C A T A_{i t-1}$ is the adjustment required to reach the firm's target working capital investment level. The coefficient $\lambda$ measures the speed of adjustment or the capacity of the firm to reach its desired working capital investment level. The coefficient $\lambda$ is inversely related to adjustment costs and takes values between 0 and 1 . If $\lambda$ is 0 , then $C A T A_{i, t}=C A T A_{i, t-1}$, indicating that firms face high adjustment costs such that the current level of working capital investment remains as in the previous period. On the contrary, if $\lambda$ is 1 , then $y_{i t-1}=y_{i t}^{*}$, indicating that firms immediately adjust their working capital investment to their target.

The target working capital investment model is estimated as follows: 


$$
\operatorname{CATA}_{i t}^{*}=\alpha+\sum_{k} \delta_{k} X_{k i t}+v_{i t}
$$

Where firms are represented by subscript $i=1, \ldots, N$ and time by $t=1, \ldots, T$ and $X_{i t}$ is a $K \times 1$ vector of explanatory variables, $\delta_{k}$ is a vector of the unknown parameters to be estimated and $v_{i t}$ the random disturbance.

Substituting (2) into (3) yields an equation that expresses the working capital investment model as determined by the following expression:

$$
\text { CATA }_{i t}=\rho+\beta_{0} \text { CATA }_{i t-1}+\sum_{k} \delta_{k} X_{k i t}+\varepsilon_{i t} \ldots \ldots \ldots(A 4
$$

Where $\rho=\alpha \lambda$; $\beta_{0}=(1-\lambda) ; \beta_{k}=\left(1-\lambda \delta_{k}\right)$ and $\varepsilon_{i t}=\lambda v_{k i t}$.

Working capital investment decisions are influenced by several individual characteristics that are difficult to measure. $\eta_{i}$, which is assumed constant but varying across firms, is introduced to capture such effects. $\eta_{t}$, which is assumed to change over time but equal for all firms, is also introduced to capture unobservable time effects. These are included in Equation A3 and the resultant estimation model is given below

$$
C A T A_{i t}=\rho+\beta_{0} C A T A_{i t-1}+\sum_{k} \delta_{k} X_{k i t}+\eta_{i}+\eta_{t}+\varepsilon_{i t}
$$

